\title{
Sistem Informasi Manajemen Perguruan Tinggi Dalam Bidang Pendataan Pendidikan Tinggi
}

\author{
Bambang S. Joko \\ bambang_tito@yahoo.com
}

\begin{abstract}
Abstrak: Tujuan studi deskriftif ini adalah untuk mengetahui berbagai permasalahan dan hambatan, mekanisme pendataan, serta pemanfaatan teknologi informasi dan komunikasi (TIK) dalam mendukung sistem informasi manajemen perguruan tinggi. Pendekatan yang dilakukan adalah pendekatan kuantitatif melalui observasi atau pengukuran data untuk mendapatkan gambaran permasalahan yang dihadapi PT. Sampel studi terdiri atas 30 PTN dan 30 PTS dari 30 provinsi di Indonesia yang dipilih secara stratified random sampling. Teknik analisis data dilakukan secara kualitatif, yakni secara deskriptif argumentatif dengan langkah-langkah pendeskripsian data, analisis data, dan penyimpulan. Hasil studi menunjukkan bahwa sebagian PT telah melaksanakan pengumpulan dan pengolahan data secara rutin setiap tahun. Pendataan didominasi oleh pengumpulan data melalui instrumen kuesioner, baik oleh Ditjen Dikti maupun oleh PSP Balitbang Depdiknas. Dua penyebab utama terhambatnya pendataan dari Ditjen Dikti dan PSP Balitbang Depdiknas dan dari institusi PT itu sendiri. SDM merupakan hambatan yang dominan dalam pengelolaan SIM PT dan belum semua PT yang menjadi sampel studi memiliki SIM PT, dan hampir separuh responden menunjukkan bahwa belum semua aplikasi SIM PT beroperasi dengan baik.
\end{abstract}

Kata Kunci: sistem informasi manajemen, pendidikan tinggi, pendataan.

\begin{abstract}
Abstrak: The purpose of descriptive research is to determine the objective conditions of the problems and constraints, data collection mechanisms, and use of information and communication technology to support higher education management information system. The approach used is kunatitatif approach that leads to the observation or measurement data expressed in numbers to get a picture of the problems faced by PT. This sample includes 30 countries and 30 private universities from 30 provinces in Indonesia. Please note, there are currently 83 government-run public universities, private universities and 2598 are managed by the private sector. With stratified random sampling method. PT PT grouped by type, then from each PT group took some samples to represent the 30 provinces. In qualitative data analysis techniques, namely descriptive measures argumentative with data description, data analysis, and conclusions. Study results showed that the majority of PT has conducted data collection and processing on a regular basis every year. Documenting all this walking is still dominated by the instrument of data collection via questionnaires, either by the Directorate General of Higher Education and Ministry of Education Research and Development Center for Education Statistics. There are two main causes of delay in data collection, the first coming from the government (Directorate General of Higher Education Department of Education and Research and Development PSP), and the second coming of PT's own institution. Not to mention, there were respondents who felt not received a census questionnaire. The dominant constraints in SIM management of PT is a problem of human resources, and yet all the PT who become SIM PT sample of this study, and nearly half of the respondents complained that some of the applications used for SIM PT they are still not operating correctly.
\end{abstract}

Keywords: management information system, higher education, data collection

\section{Pendahuluan}

Keberadaan perguruan tinggi sebagai salah satu ujung tombak peningkatan sumber daya manusia di bidang pendidikan adalah suatu kenyataan yang tidak terbantahkan. Perguruan tinggi sebagai sebuah institusi yang sangat kompleks, memerlukan tolok ukur yang bisa dijadikan acuan dalam menilai keberhasilan dalam pengelolaannya. Salah satu tolok ukur utama yang dapat digunakan adalah keberadaan sistem informasi. Suatu 
perguruan tinggi yang dikelola dengan sistem informasi yang baik akan mampu mengendalikan manajemen institusi dengan baik.

Sistem informasi manajemen (manajement information system) yang sering dikenal dengan singkatan MIS merupakan penerapan sistem informasi di dalam organisasi untuk menyediakan informsi-informasi yang dibutuhkan oleh semua tingkatan manajemen. Sistem Informasi Majemen (SIM) dapat didenfinisikan sebagai kumpulan interaksi sistem-sistem informasi yang bertanggung jawab mengumpulkan dan mengelola data untuk menyediakan informasi yang berguna untuk semua tingkatan di dalam kegiatan perencanaan dan pengendalian.

Sebagian penunjang SIM, peran Teknologi Informasi (TI) sebagai bagian dari Sistem Informasi (SI) telah mengalami perubahan secara dramatis. Saat ini, TI tidak hanya ditempatkan sebagai perangkat pembantu kegiatan berorganisasi tetapi sudah menjadi strategi organisasi untuk mencapai tujuan. Institusi perguruan tinggi adalah sebuah organisasi akademis yang menggunakan teknologi informasi dalam membentuk berbagai proses bisnis di dalamnya. Bentuk organisasi ini memiliki karakter tersendiri yang bersifat khas sehingga bentuk sistem informasi yang diperlukan pun haruslah memiliki karakter tersendiri.

Paradigma baru pengelolaan pendidikan tinggi yang muncul seiring dengan lahirnya PP 61, Tahun 1999 tentang otonomi PT, telah melahirkan berbagai pergeseran sistem manajemen internal PT. PP 61, Tahun 1999 lahir dari keinginan untuk meningkatkan pelaksanaan sistem desentralisasi PT, khususnya bagi PTN. Pengambilan berbagai kebijakan pendidikan tinggi pada saat ini relative terpusat di Ditjen Dikti, berikutnya secara bertahap akan diberikan kepada masing-masing PT. Hal ini memberikan keleluasaan yang lebih tinggi bagi pimpinan PT untuk mengatur pemanfaatan sumber daya yang dimiliki sesuai dengan visi dan misi PT yang bersangkutan. Konsekuensi ini melahirkan perlunya sistem yang mampu untuk mensinergikan segala sumber daya yang ada, sehingga akan meningkatkan derajat penyatuan sumber daya atau semacam sentralisasi pada tingkat internal PT untuk mengoptimalisasi pemanfaatan sumber daya.
Berdasarkan hal tersebut, ada lima indikator kunci kinerja yang harus memenuhi standar minimal kriteria kelayakan dalam pengelolaan/ manajemen, yaitu: 1) Penyelenggaraan program pendidikan tinggi seperti sistem dan mekanisme kerja; 2) Infrastruktur seperti tanah, gedung, peralatan dan fasilitas lainnya; 3) Finansial seperti struktur pemasukan, pengeluaran dan penggunaan dana; 4) Aset sumber daya manusia seperti sistem rekruitmen mahasiswa, rekuitmen dan pengembangan staf pengajar serta staf pendukung lainnya; dan 5) Informasi seperti online internal connectivity melalui sistem informasi manajemen yang baik.

Dari segi jumlah lembaga PT yang demikian besar, merupakan masalah mendasar terkait dengan cara mengkoordinasikan agar seluruh PT yang ada tetap berjalan sesuai dengan visi dan misi pendidikan. Kesulitan mengkoordinasikan oleh pemerintah sebagai Pembina PT tersebut muncul karena perguruan-perguruan tinggi nasional tersebut memiliki kemampuan yang terbatas dalam menyediakan dan menyadikan informasi yang terkait dengan kondisi pendataan PT yang hingga saat ini belum begitu baik. Ditjen Dikti dan PSP Balitbang Depdiknas sangat berkepentingan dalam hal pembinaan maupun pendataan. Berdasarkan Peraturan Mediknas Nomor 38 Tahun 2008, Pasal 9 Ayat 2 dan Ayat 3, menyebutkan PSP Balitbang Depdiknas ditunjuk sebagai pengelola pangkalan data pendidikan dan pengelolaan sistem pendukung keputusan departemen, mulai dari pendataan jenjang pendidikan dasar dan menengah, pendidikan nonformal hingga pendidikan tinggi.

Dari data statistik PT, terdapat 83 Perguruan Tinggi Negeri (PTN) yang diselenggarakan oleh Departemen Pendidikan Nasional (Depdiknas) tersebar di 30 provinsi, dan 2.598 Perguruan Tinggi Swasta (PTS) yang diselenggarakan oleh masyarakat yang terbagi dalam 12 wilayah Kopertis.

Secara umum, sistem informasi manajemen (SIM) PT di Indonesia saat ini terkendala oleh berbagai permasalahan seperti belum terintegrasinya sistem komputerisasi yang ada di PT, keterbatasan SDM dalam pengoperasian komputer, sistem pendataan yang belum terpusat sehingga sebagian besar PTN dan PTS yang ada 
belum mampu menyajikan informasi secara cepat dan tepat waktu.

Lebih dari itu, keberadaan SIM PT dapat pula menjadi tolok ukur kesiapan dalam memasuki era informasi perguruan tinggi. Sebagai langkah awal dalam upaya mempersiapkan perguruan tinggi tersebut, perlu dimulai dengan membangun jaringan informasi yang berbasis pangkalan data untuk mendapatkan informasi pendataan di setiap unit-unit kerja di lingkungan perguruan tinggi.

Data yang absah, lengkap dan aktual merupakan masukan utama untuk menghasilkan informasi yang benar, akurat, serta mutakhir, yang pada akhirnya bermuara pada keputusan/ kebijakan yang dapat di terima, tepat sasaran, serta tepat waktu. Namun, kegiatan penyediaan dan pengolaan data, khususnya di bidang pendidikan tinggi masih memiliki permasalahan. Studi ini menggunakan rumusan masalah deskriptif yang artinya rumusan masalah yang berkenaan dengan pertanyaan terhadap keberadaan variable mandiri baik pada hanya satu variable atau lebih (variable yang berdiri sendiri) dan tidak membuat perbandingan variable pada sampel lain. Perumusan masalah kajian ini antara lain: 1). Permasalahan apa yang menghambat kaulitas dan kuantitas pendataan pendidikan tinggi selama ini? 2). Bagaimana mekanisme pendataan pendidikan di perguruan tinggi? 3). Bagaimana sebagai penunjang pelaksanaan sistem informasi manajemen perguruan tinggi?

Tujuan studi sistem informasi manajemen perguruan tinggi dalam pendataan pendidikan tinggi, yaitu: 1) Mengamati secara langsung permasalahan yang menjadi penghambat peningkatan kualitas dan kuantitas pendataan pendidikan tinggi; 2) Memperoleh gambaran tentang mekanisme pendataan pendidikan tinggi; dan 3) Mengetahui pemanfaatan teknologi dan informasi pendidikan dalam pendataan pendidikan sebagai penunjang pelaksanaan sistem informasi manajemen perguruan tinggi.

\section{Kajian Literatur}

\section{Sistem Informasi Manajemen}

Sistem informasi manajemen (SIM) merupakan penerapan sistem informasi di dalam organisasi untuk menyediakan informasi-informasi yang dibutuhkan oleh semua tingkatan manajemen. SIM dapat didefinisikan sebagai kumpulan interaksi sistem-sistem Informasi yang bertanggung jawab mengumpulkan dan mengolah data untuk menyediakan informasi yang berguna untuk semua tingkatan manajemen di dalam kegiatan perencanaan dan pengendalian.

Semua sistem informasi memiliki tiga unsur atau kegiatan utama, yaitu: 1) menerima data sebagai masukan (input); 2) memproses data dengan melakukan perhitungan, penggabungan unsur data, pemutakhiran, perkiraan, dan lainlain; dan 3) memperoleh informasi sebagai keluaran (output). Prinsip ini berlaku baik untuk sistem informasi manual, elektromekanis maupun komputer.

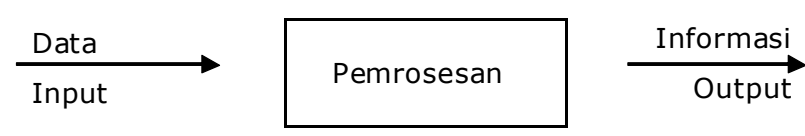

Secara sederhana dapat dikatakan bahwa sebuah sistem informasi akan memproses data dan kemudian mengubahnya menjadi informasi.

\section{Sistem Informasi Manajemen Perguruan Tinggi}

PT sebagai suatu sistem yang sangat besar, memiliki sub-sub sistem yang banyak sehingga masing-masing membentuk pola hubungan kerja yang mewujudkan sebuah sentralisasi sistem yang bekerja secara harmonis, saling dukungmendukung dan terkait satu dengan yang lain.

SIM-PT diharapkan dapat menjadi salah satu solusi yang dapat membantu menyelesaikan permasalahan-permasalahan manajemen di setiap tata kelola PT yang ada. Untuk menghasilkan sebuah sistem informasi agar terintegrasi dengan baik perlu diperhatikan tiga hal: Pertama, sistem informasi didefinisikan secara jelas dan terperinci sehubungan dengan jenis-jenis informasi apa yang dibutuhkan oleh institusi. Halhal yang berkaitan dengan kecepatan proses pengolahan data menjadi informasi, tingkatan detail informasi, cara penampilan informasi. Kedua, adanya teknologi infrastruktur, alat komunikasi, dan lain-lain) dan perangkat lunak (aplikasi, sistem operasi, database, dan lain-lain) yang harus tersedia. Ketiga, adanya manajemen informasi, 
yang menyangkut perangkat manusia (brainware) yang akan mengimplementasikan sistem informasi yang dibangun dan yang akan mengembangkan teknologi informasi.

Karakteristik SIM-PT adalah menjadi sarana pendukung lembaga pendidikan tinggi untuk mencapai tujuan memberikan layanan yang diperlukan masyarakat akademis secara memuaskan, andal dan terjangkau, menaikkan mutu pelayanan sesuai dengan misi pendidikan tinggi, dan memberikan informasi yang akurat dan luar institusi.

\section{Mekanisme Pendataan Pendidikan Tinggi}

Pengumpulan data pendidikan tinggi (PT) merupakan kegiatan Pusat Statistik Pendidikan (PSP), Badan Penelitian dan Pengembangan (Balitbang) Departemen Pendidikan Nasional (Depdiknas). Kegiatan ini bertujuan untuk memperoleh data dan informasi mengenai pendidikan tinggi. Data tersebut disimpulkan dalam rangka penyusunan statistik, pengembangan pangkalan data, perencanaan, pengambilan keputusan dan penentuan kebijakan. Pendataan PT meliputi seluruh pendidikan tinggi umum, keagamaan, dan kedinasan, baik negeri maupun swasta. Instrumen pendataan yang digunakan adalah kuesioner individu perguruan tinggi, yang diberi kode LI-PT. Waktu hitung (counting date) yang digunakan dalam pendataan PT adalah per 30 September dengan pertimbangan pada tanggal tersebut proses registrasi mahasiswa baru dan lama sudah selesai dilakukan.

Responden adalah pimpinan perguruan tinggi atau pejabat yang ditugasi dan bertanggung jawab dalam pengisian kuesioner, termasuk obyektivitas dan akurasi data serta ketepatan mengikuti jadwal pendataan yang telah di tetapkan.

Penyebaran instrument dilakukan dengan mengirimkan kuesioner LI-PT ke PT, selanjutnya PT menerima kuesioner LI-PT. Untuk pengembalian, PT menerima kuesioner LI-PT dari Balitbang Depdiknas, mengisi kuesioner LI-PT, kemudian dokumen kuesioner yang telah terisi oleh PTN dan PTS mengirim kembali ke PSP Balitbang Depdiknas, PTS mengirim arsip kuesioner ke Kopertis, serta menyimpan arsip LI-PT yang telah terisi.

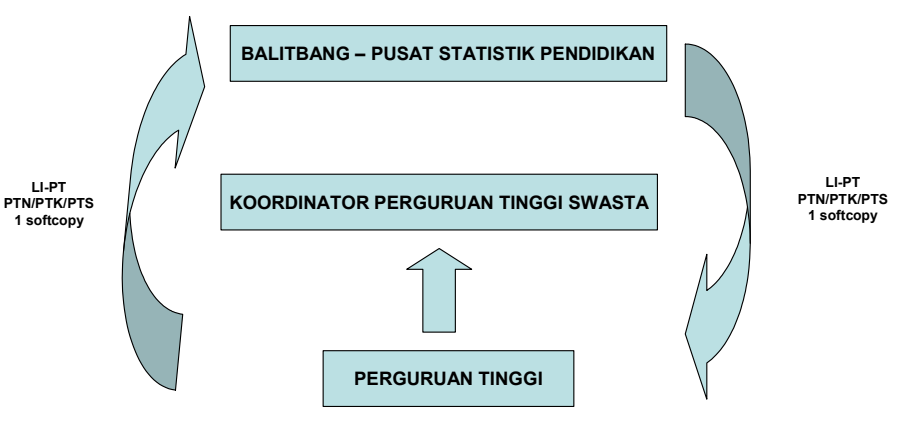

Gambar 1. Mekanisme Pendataan PT

\section{Metodologi}

Metode dan prosedur penelitian merupakan cara kerja yang ditempuh untuk mendapatkan informasi yang diperlukan untuk memahami obyek yang menjadi sasaran penelitian. Dalam studi ini, prosedur penelitian ditunjukkan untuk mendapat sistem informasi manajemen pendidikan tinggi yang berjalan saat ini serta permasalahan yang muncul dalam kegiatan kerja sama pendataan pendidikan tinggi tersebut. Menurut Sekaran (2000) ada 3 jenis penelitian, yaitu: 1) exploratory research, yaitu penelitian yang bertujuan untuk mencari kejelasan suatu masalah; 2) descriptive research, penelitian yang bertujuan untuk mencari deskripsi suatu objek; dan 3) verificative research (explanatory research), penelitian yang bertujuan untuk mengetahui kejelasan hubungan variable (menguji hipotesis). Studi ini termasuk jenis penelitian deskriptif (descriptive research), karena ingin mengetahui dan sekaligus menggambarkan bagaimana kondisi objektif tentang mekanisme pendataan yang dilakukan oleh PTN dan PTS serta permasalahan-permasalahan yang muncul dalam kerja sama pendataan tersebut.

Pendekatan yang digunakan adalah pendekatan kuantitatif. Penelitian kuantitatif bertitik tolak dari paradigma fenomenologis yang obyektivitasnya dibangun dari rumusan situasi tertentu yang dihayati oleh individu atau kelompok social tertentu, dan relevan dengan tujuan dari penelitian. Selain itu, pada umumnya penelitian kuantitatif mengarah pada observasi atau pengukuran data yang dinyatakan dalam angkaangka. Dengan kata lain, penelitian yang bersifat kuantitatif lebih diutamakan pada pengumpulan data yang dapat diukur. Pendekatan kuantitatif digunakan untuk mendapatkan gambaran 
permasalahan yang dihadapi oleh PTN dan PTS dalam rangka mengupayakan peningkatan dan pemberdayaan sistem informasi manajemen perguruan tinggi.

\section{Populasi dan Sampel}

Dalam suatu penelitian, populasi yang lebih dipilih mempunyai hubungan yang erat dengan masalah yang diteliti. Populasi atau universe adalah seluruh elemen yang dapat digunakan untuk membuat beberapa kesimpulan (Cooper dan Schindler, 2001). Populasi penelitian ini adalah seluruh perguruan tinggi baik negeri maupun swasta yang berada dalam pengawasan departemen pendidikan nasional, yang keseluruhan berjumlah 2.681 (83 PTN dan 2.598 PTS), yang tersebar di seluruh wilayah Indonesia. Pada saat studi ini dilakukan, dari 33 provinsi yang ada di Indonesia hanya 30 provinsi yang memiliki PTN. Sementara 3 provinsi lainnya yaitu provinsi Kepulauan Riau, Bangka Belitung, dan Sulawesi Barat, belum mempunyai PTN. Oleh karena itu, populasi provinsi ditetapkan 30 provinsi.

Sampel merupakan elemen populasi yang merupakan subjek pengukuran dari unit penelitian yang memberikan kesimpulan tentang seluruh populasi (Cooper dan Schinlder, 2001). Pemilihan sampel untuk penelitian ini dengan metode stratified random sampling. Populasi dikelompokkan berdasarkan PT masing-masing, selanjutnya dari masing-masing kelompok akan diambil beberapa sampel dengan metode Simple Random Sampling (Sekaran,2000:283). Dari 30 provinsi yang ditetapkan sebagai populasi, untuk masing-masing provinsi diambil sampel 1 PTN dan 1 PTS. Pengambilan sampel PTN dan PTS untuk masing-masing provinsi ini ditetapkan dengan menggunakan metode pengambilan sampel acak sederhana (simple random sampling). Pertama diambil 30 PTN yang masing-masing mewakili 30 provinsi yang ditetapkan. Kedua, dengan metode yang sama dipilih 30 PTS yang mewakili 3 provinsi.

\section{Instrumen}

Instrumen yang digunakan dalam studi adalah daftar pertanyaan yang terdiri dari pertanyaanpertanyaan tertutup dan pertanyaan terbuka. Item-item pertanyaan tertutup berbentuk pilihan paksa (forced choice), responden diminta untuk memilih satu atau lebih pilihan yang telah diberikan. Pertanyaan terbuka digunakan untuk menggali dan mendapatkan informasi tentang permasalahan-permasalahan yang dihadapi responden terkait dengan SIM PT.

\section{Pengumpulan dan Analisis Data}

Untuk menganalisis data yang diperoleh dari pengumpulan data di lapangan dilakukan analisis deskriptif kuantitatif sehingga diperoleh informasi tentang kecenderungan fenomena yang dikaji. Selanjutnya, berdasarkan temuan dan diskusi dilakukan penarikan simpulan tentang semua hasil pelaksanaan kegiatan penelitian di 30 provinsi yang menjadi sampel penelitian dan merumuskan saran-saran kebijakan berdasarkan hasil penelitian yang diperoleh dalam rangka meningkatkan kualitas kerjasama antar lembaga pengelola SIM pendataan PT negeri maupun swasta.

\section{Hasil Penelitian dan Pembahasan}

\section{Mekanisme Pendataan di Perguruan Tinggi}

Mekanisme pendataan PT di lingkungan Depdiknas dilaksanakan oleh Ditjen Dikti yang merupakan unit kerja utama yang langsung membawahi PT dan PSP Balitbang, Depdiknas.

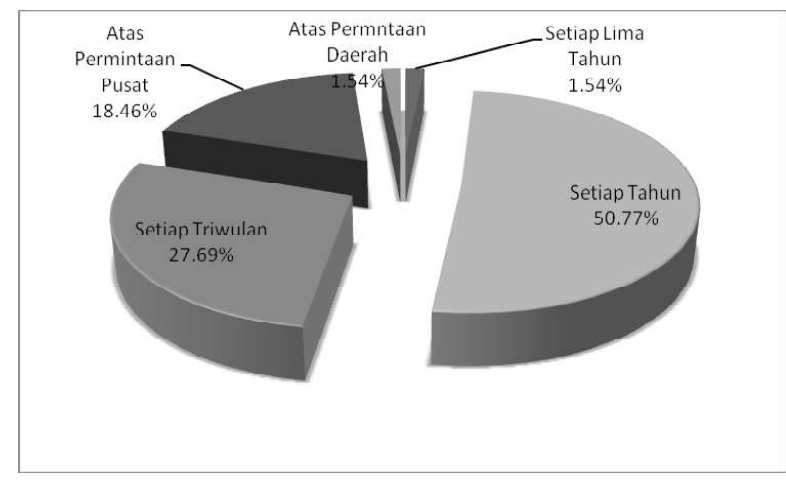

Gambar 2. Pelaksanaan Pengupulan dan Pengolahan Data Secara Rutin

Dari data pertama diatas, menunjukkan bahwa lebih dari separuh $(50,77 \%)$ PT yang menjadi responden studi ini melaporkan bahwa mereka telah melaksanakan pengumpulan dan pengolahan data secara rutin setiap tahun. Sebanyak $27.59 \%$ responden melakukan pengumpulan dan pengolahan data secara berkala setiap tiga bulan dan sebanyak $1.54 \%$ 
responden melakukan pendataan, setiap lima tahun sekali. Selain pengumpulan data secara berkala tersebut, perguruan tinggi yang menjadi responden studi ini juga melaksanakan kegiatan pendataan dan permintaan setiap daerah sebanyak $(1.54 \%)$ dan atas permintaan pusat sebanyak (18.46\%).

Responden melaporkan bahwa unit kerja yang bertanggung jawab menangani dan mengolah data institusi adalah Biro Administrasi Akademik dan Kemahasiswaan (BAAK) yaitu $32.05 \%$. Sebanyak $17.9 \%$ responden menjawab Biro Administrasi Akademik dan Perencanaan Sistem Informasi (BAAKSI), $16.7 \%$ responden menjawab Biro Administrasi Perencanaan dan Sistem Informasi (BAPSI), $11.51 \%$ responden menjawab Biro Administrasi Umum (BAU), 5.1\% responden menjawab Tata Usaha, dan sisanya sebesar $16.7 \%$ responden menjawab dari unit kerja lain antara Puskom (Pusat Pengembangan dan Pelayanan Sistem Informasi), Pupstik (Pusat Teknologi Informasi dan Komunikasi), UPT (Unit Informasi Teknologi), dan lain-lain.

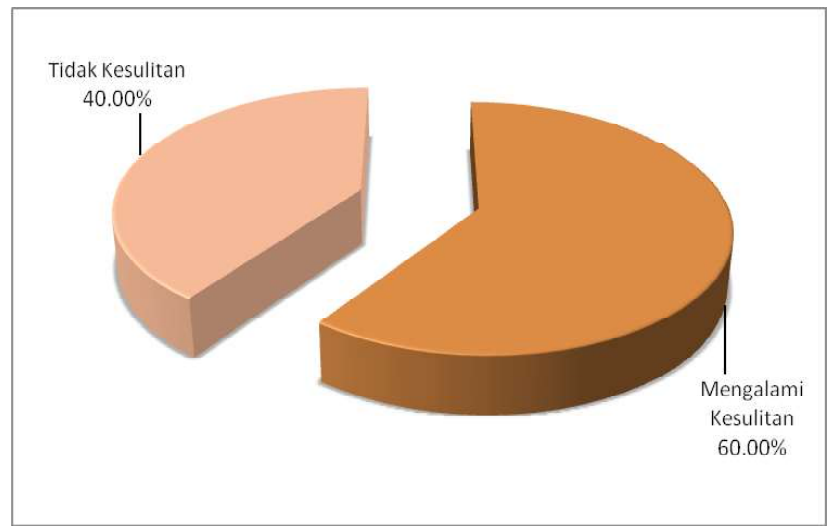

Gambar 3. Kesulitan Dalam Pengisian Kuesioner

Dari $50 \%$ responden yang menerima kuesioner PSP Balitbang, pada data kedua diatas menunjukkan bahwa sebanyak $40 \%$ responden mengaku tidak mengalami kesulitan untuk mengisi dan menyediakan data yang diperlukan, sedangkan $60 \%$ responden lainnya mengaku masih mengalami kesulitan karena berbagai alasan. Alasan-alasan tersebut antara lain adalah format pengisian terlalu bervariasi, item yang diminta terlalu banyak, sistem data (informasi data) belum terintegrasi, dan keterlambatan instrumen yang digunakan untuk pengumpulan data.

\section{Permasalahan Dalam Pengalolaan SIM PT}

Berbagai hambatan dalam pengelolaan SIM PT yang paling dominan adalah masalah SDM. Hal ini dibuktikan oleh sebanyak $25.20 \%$ menyatakan kurangnya jumlah SDM dan skill yang dimiliki SDM. Permasalahan-permasalahan lainnya seperti infrastruktur, sarana dan prasarana, dijawab oleh sebanyak $17.32 \%$, program aplikasi (software) sebanyak $12.60 \%$, dan koordinasi juga sebanyak $7.87 \%$. Selain itu, muncul permasalahan yang terkait dengan keterbatasan dana dan anggaran, perencanaan dan pemanfaatan jaringan, pengumpulan dan up dating data. Permasalahan yang muncul dalam pengelolaan SIM PT ditunjukkan pada data dibawah ini.

\section{Pemanfaatan Teknologi Informasi dalam Pendataan}

Pemanfaatan teknologi informasi sangat berperan dalam pengumpulan dan pengelolaan data PT. Pada bagian ini disajikan temuan-temuan studi yang terkait dengan operasionalisasi SIM PT dan optimalisasi pemanfaatan SIM PT tersebut dalam proses pengumpulan dan pengolahan data PT.

\section{Operasionalisasi SIM PT}

Berdasarkan hasil pengumpulan data diperoleh informasi bahwa secara keseluruhan, saat ini belum seluruh institusi responden dalam studi ini memiliki SIM PT. Sebanyak $71.67 \%$ responden melaporkan bahwa institusi mereka telah memiliki SIM PT, sementara sisanya sebesar $28.33 \%$ responden mengakui bahwa institusi mereka belum memiliki SIM PT.

Jika dilihat untuk masing-masing PTN dan PTS, jumlah PT yang sudah memiliki SIM PT dengan yang belum memiliki SIM PT hamper seimbang. Sebanyak 73.33\% PTN di Indonesia telah memiliki dan mengoperasikan SIM PT untuk keperluan pendataan di lingkungan institusi mereka. Sisanya, sebanyak 26.67\% PT belum memiliki SIM PT. Untuk PTS, sebanyak 70\% PTS telah memiliki dan mengoperasikan SIM PT untuk keperluan pendataan di lingkungan institusi mereka. Sisanya, $30 \%$ PTS belum memiliki SIM PT. 
Tabel 4. Permasalahan-Permasalahan Perguruan Tinggi dalam Pengelolaan SIM PT

\begin{tabular}{|c|c|c|c|}
\hline No. & Permasalahan & $\begin{array}{l}\text { Frekuensi } \\
\text { Jawaban }\end{array}$ & Persentase \\
\hline 1. & Masalah SDM baik dari segi kualifikasi maupun jumlahnya & 32 & 25.20 \\
\hline 2. & $\begin{array}{l}\text { Sarana prasarana dan infrastruktur termasuk hardware masih } \\
\text { sangat kurang dan terbatas }\end{array}$ & 22 & 17.32 \\
\hline 3. & $\begin{array}{l}\text { Program aplikasi (software) yang digunakan belum sempurna, tidak } \\
\text { cocok dengan SIM PT dan terus mengalami perkembangan }\end{array}$ & 16 & 12.60 \\
\hline 4. & $\begin{array}{l}\text { Koordinasi antar unit-unit kerja dan koordinasi SDM juga masih } \\
\text { kurang }\end{array}$ & 10 & 7.87 \\
\hline 5. & Keterbatasan dana dan anggaran & 8 & 6.30 \\
\hline 6. & Perencanaan dan pemanfaatan jaring an masih kurang & 6 & 4.72 \\
\hline 7. & Pengumpulan dan update data & 5 & 3.94 \\
\hline 8. & $\begin{array}{l}\text { Updating dan peningkatan feature untuk mengikuti perubahan di } \\
\text { Lembaga }\end{array}$ & 4 & 3.15 \\
\hline 9. & Belum banyak pihak yg memamahami manfaat SIM dan data & 4 & 3.15 \\
\hline 10. & Integrasi sistem data dan sistem pengolahan data & 4 & 3.15 \\
\hline 11. & Permasalahan yang berasal dari pengguna (user) & 4 & 3.15 \\
\hline 12. & Organisasi kelembagaan dan pengelolaan SIM & 3 & 2.36 \\
\hline 13. & Permasalahan perawatan sistem infrastruktur & 3 & 2.36 \\
\hline 14. & Sistem tidak bisa bekerja secara cepat dan efisien & 2 & 1.57 \\
\hline 15. & Kondisi aliran listrik yg belum stabil & 1 & 0.79 \\
\hline 16. & Sosialisasi stan dar operasional prosed ur pemanfaatan ICT & 1 & 0.79 \\
\hline 17. & $\begin{array}{l}\text { Kapasitas bandwide dari provider swasta yg berlangganan sang at } \\
\text { lemah }\end{array}$ & 1 & 0.79 \\
\hline 18. & Keamanan data & 1 & 0.79 \\
\hline
\end{tabular}

Mayoritas responden melaporkan bahwa dalam pengembangan dan operasionalisasi SIM PT, lembaga mereka melibatkan berbagai unit kerja lain seperti fakultas, jurusan, dan program studi. Sebanyak $95.65 \%$ responden melaporkan bahwa mereka telah melibatkan unit-unit kerja tersebut dalam pengembangan dan operasionalisasi SIM PT, dan hanya $4.35 \%$ responden mengakui bahwa mereka tidak melibatkan fakultas, jurusan, dan progam studi dalam pengembangan dan operasionalisasi SIM PT.

Pada data dibawah ini menunjukkan tingkat operasional/keberjalanan SIM PT. Sebanyak $57.14 \%$ responden melaporkan bahwa SIM PT di lembaga mereka sudah beroperasi dengan baik. Namun, terdapat $42.86 \%$ responden, mengakui bahwa SIM PT mereka belum beroperasi dengan baik.

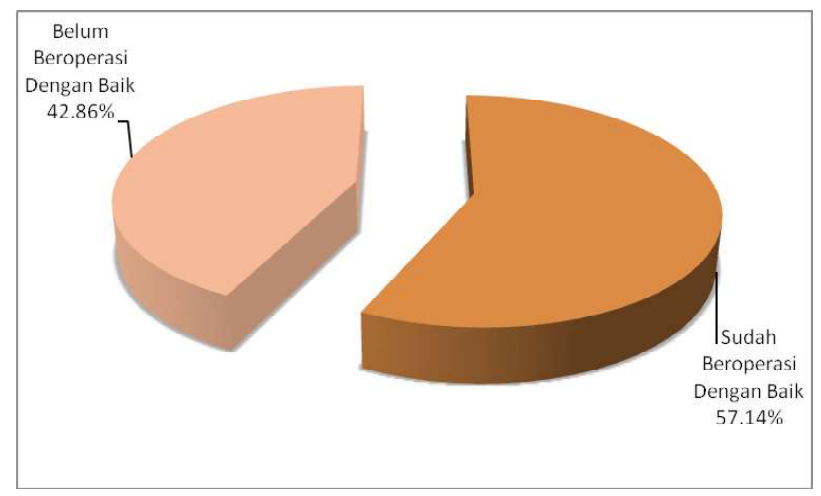

Gambar 4. Tingkat Operasional SIM PT

Untuk perancangan aplikasi SIM PT, sebanyak $6.82 \%$ responden mengakui bahwa lembaga mereka telah merancang berbagai aplikasi/program yang cocok untuk digunakan dalam SIM PT mereka. Sebanyak $45.45 \%$ responden lainnya melaporkan hasil yang berbeda, SIM PT di lembaga mereka telah menggunakan berbagai aplikasi/program yang dirancang cocok dengan SIM PT di 
lembaga mereka. Namun, ditemukan sebanyak $47.73 \%$ responden yang merasa bahwa hanya sebagian aplikasi yang sudah dirancang cocok untuk digunakan dengan SIM PT mereka, diantaranya adalah Keuangan, Akademik, Kepegawaian, Asset; Aplikasi SIM Akademik, Kepegawaian dan Keuangan; Data Dosen, Data Mahasiswa; Sistem Informasi Akademik (SIAK), Sistem Informasi Kepegawaian dan Akademik (SIPEKA), Education Learning (E-Learning), Education Library (E-Lib), Sistem Informasi Manajemen Penerimaan Mahasiswa Baru (SIM-PMB), Evaluasi progam Studi Berbasis Evaluasi Diri (EPSBED), Sistem Administrasi Inventaris, dan lain-lain.

Sementara itu, untuk tingkat operasional dan mengembangkan aplikasi SIM PT, lebih dari separuh responden $(53.33 \%)$ melaporkan bahwa aplikasi-aplikasi yang diadopsi untuk SIMPT mereka telah beroperasi dengan baik. Sebaliknya, sebanyak $46.67 \%$ responden lainnya mengeluhkan bahwa beberapa aplikasi yang digunakan untuk SIM PT masih belum beroperasi dengan baik. Berbagai penyebaba belum beroperasinya aplikasi tersebut, antara lain penekanan masih pada akademik sehingga SIM lainnya belum ditangani dengan baik, keterbatasan sarana, SDM yang mengoperasikan dan mengelolanya belum mapan dan sedang dilatih, belum sesuai dengan instrument EPSBED yang setiap semester diisi sehingga harus dikerjakan berulang-ulang, serta proses integrasi untuk semua sisitem informasi yang direncanakan akhir tahun 2008 baik sarana maupun prasarana terutama computer server belum memadai masih dalam tahap perencanaan, dan lain-lain.

\section{Optimalisasi Pemanfaatan SIM PT}

Terkait dengan pendataan yang dilakukan oleh pusat terhadap PT, tidak seluruh institusi yang menjadi sampel penelitian ini sudah memiliki pangkalan data yang mampu menyediakan berbagai data dan informasi yang diminta. Sebanyak $39.02 \%$ responden melaporkan bahwa keseluruhan data yang diminta oleh pusat sudah tersedia pada pangkalan data yanag dimiliki oleh institusi/lembaga mereka, dan sebanyak $4.88 \%$ responden melaporkan bahwa data yang diminta pada umumnya tidak tersedia pada pangkalan yang dimiliki institusi mereka.
Untuk institusi-institusi yang belum memiliki SIM PT, mereka mendapatkan data yang diperlukan melalui berbagai cara-cara konvensional. Sebagian besar sebanyak $61.22 \%$ responden melaporkan bahwa mereka mendapatkan data dengan meminta kepada unit-unit kerja terkait pada saat data tersebut dibutuhkan. Sebanyak $32.65 \%$ responden lainnya mengakui bahwa mereka mendapatkan data yang diperlukan dari laporan-laporan periodik yang mereka terima. Sisanya sebanyak $6.12 \%$ responden melaporkan bahwa data yang diperlukan institusi didapat dari web data base dan mengandalkan tata usaha untuk menyediakannya.

Untuk keperluan pengolahan data, sebanyak $39.74 \%$ responden mengatakan bahwa mereka menggunakan software khusus. Sebanyak 35.9\% responden mengakui bahwa mereka masih menggunakan aplikasi MS Excel untuk keperluan pengolahan data yang mereka lakukan. Sisanya, sebanyak $24.36 \%$ responden mengatakan bahwa mereka menggunakan berbagai program aplikasi yang dibuat sendiri seperti menggunakan program; Visual Foxpro Java, MS-ACCESS; Delphi; Sistem Inventarisasi (Diknas), Visual Basic, My SQL, serta Php, SQL, Visual Foxpro, dan lain-lain.

\section{Pembahasan}

\section{Mekanisme Pendataan di Perguruan Tinggi}

Studi ini menemukan bahwa masih terdapat 1.54\% responden melakukan pendataan setiap lima tahun sekali. Temuan ini mengisyaratkan bahwa penyediaan data dan informasi untuk kebutuhan pengambilan keputusan masih dianggap belum begitu memegang peranan penting. Padahal di abad informasi seperti sekarang ini, keputusan dan kebijakan seharusnya didasarkan pada informasi yang akurat, mengingat dampak kebijakan akan berdampak pada masyarakat sehingga bila terjadi salah kebijakan maka akan menimbulkan kerugian besar.

Meskipun dalam jumlah yang sangat kecil, studi ini juga menemukan bahwa baik pusat maupun pemerintah daerah pada dasarnya telah melakukan kerja sama pendataan dengan perguruan tinggi. Hal itu diindikasikan dengan adanya kegiatan pendataan yang dilakukan responden atas permintaan daerah sebanyak $(1.54 \%)$ dan atas permintaan pusat sebanyak 
$(18.46 \%)$. Dengan sangat kecilnya presentase responden melaporkan adanya permintaan pusat dan daerah untuk melakukan pendataan mengidikasikan bahwa baik pemerintah pusat maupun daerah masih kurang memberikan perhatian bagi pengembangan pendidikan tinggi.

Studi ini menemukan bahwa terdapat banyak unit kerja yang menangani pendataan di perguruan tinggi. Temuan ini di satu sisi mengindikasikan bahwa arti pentingnya kegiatan pendataan telah disadari secara merata pada unit kerja di lingkungan PT. Namun, pada sisi lain, fenomena ini berdampak pada kesulitan pihak luar (termasuk Ditjen Dikti dan PSP, Balitbang Depdiknas) untuk menjalin kerjasama pendataan itu sendiri. Jika kerjasama tersebut harus melalui mekanisme birokrasi yang panjang maka efisien dan efektivitas pendataan menjadi sangat lemah dan mengakibatkan data yang dihasilkan tidak begitu bermanfaat lagi bagi pengambilan keputusan dan kebijakan karena sudah tidak up to date.

\section{Permasalahan Dalam Pengelolaan SIM PT}

Permasalahan yang paling sering dihadapi oleh PT dalam pengelolaan SIM PT adalah SDM, diikuti dengan sarana dan prasarana, software dan hardware, koordinasi, dan pendanaan, Perma-salahan SDM merupakan aspek yang paling banyak muncul dalam semua bidang pendidikan, termasuk dalam pengelolaan SIM PT. Selain SDM, juga muncul permasalahan software dan hardware dalam 5 besar permasalahan SIM PT. Dengan demikian, tiga unsur utama pembentuk sebuah sistem informasi, yaitu hardware, software dan brainware (milik manusia), perangkat keras sebagai komponen yang bergerak dan perangkat lunak sebagai komponen penggerak. Keduanya diurus oleh orang dengan kompetensi yang berbeda, yaitu teknis perangkat keras dan pengurus program perangkat lunak. Dengan kata lain, sistem informasi membutuhkan dukungan TIK juga membutuhkan isi (content), prosedur (procedure), dan peranan SDM (role) yang semuanya akan menuju satu kesatuan dari kebutuhan yang diharapkan institusi. Tanpa adanya proses informasi yang efektif maka institusi tersebut tidak dapat mengandalkan lingkungan sekitarnya.

Dua masalah lainnya di kelompok lima besar permasalahan yang dihadapi oleh SIM PT adalah koordinasi dan pendanaan.
Pengembangan SIM PT juga memerlukan jalinan komitmen tinggi dari semua pihak yaitu komitmen pimpinan, pengelola, maupun pengguna. Di samping itu, ketersediaan SDM sangat perlu diperhatikan. Tenaga ahli di bidang TIK masih sangat dibutuhkan di Indonesia. Yang dimaksud SDM di sini, merupakan kompetensi SDM di bidang TIK, yaitu kemampuan dan keahlian SDM dalam bidang TIK. SDM di bidang TIK di dalam negeri saat ini diakui oleh semua pihak, masih rendah karena tidak semua Departemen peduli terhadap sektor tersebut.

Karena itu faktor-faktor kunci keberhasilan pengembangan sistem pangkalan data antara lain adalah komitmen, dukungan dan partisipasi dari stakeholder, infrastruktur teknologi informasi dan komunikasi; penetapan prosedur standar yang baku; pemilihan tool atau platform yang sesuai dan dipakai secara konsisten; pembangunan sistemsistem dilakukan secara paralel dengan penyiapan dan pemasukan data; dan tim pembangun yang kompeten.

\section{Pemanfaatan Teknologi Informasi Dalam Pendataan}

\section{Operasionalisasi SIM PT}

Dari $71.67 \%$ responden yang mengakui telah memiliki SIM PT, hampir separuh atau $42.86 \%$ responden mengakui bahwa SIM PT mereka belum beroperasi dengan baik. Belum beroperasinya SIM PT tersebut disebabkan oleh berbagai aspek jaringan dan progam aplikasi (software). Terkait dengan permasalahan software yang digunakan dalam SIM PT, studi ini menemukan bahwa $45.45 \%$ responden melaporkan SIM PT di lembaga mereka telah menggunakan berbagai aplikasi/program yang dirancang cocok dengan kebutuhan lembaga mereka. Sisanya, mengakui bahwa berbagai program aplikasi yang digunakan hanya sebagian yang cocok dengan SIM PT. Hambatan ini memang mengganggu dan membatasi kemampuan sebuah sistem untuk bisa bekerja secara optimal.

Kelemahan di salah satu aspek seperti software menyebabkan sebuah SIM tidak berjalan tidak optimal. Sebagaimana telah disebutkan pada bagian sebelumnya, pengumpulan dan pengelolaan pendataan di PT hingga saat ini masih dikelola oleh berbagai unit kerja di lingkungan PT. Hal yang sama terjadi pula dalam pengelolaan SIM PT. SIM 
PT dikelola oleh berbagai unit-unit kerja di dalam institusi PT. Sebagian besar dikelola oleh BAAK (30.65\%), diikuti oleh BAU (12.9\%), BAAKSI dan BAPSI masing-masing $11.29 \%$, dan Tata Usaha (3.23\%), sedangkan $30.65 \%$ responden lainnya melaporkan bahwa SIM PT di institusi mereka dikelola oleh berbagai unit kerja lainnya. Hingga saat ini belum ada investigasi tentang unit kerja mana yang sebaiknya diserahi tanggung jawab tertentu untuk mengelola SIM PT, agar mampu beroperasi secara efektif dan efisien. Kondisi tersebut juga menguntungkan karena dengan tidak adanya keseragaman pengelolaan maka, SIM PT akan lebih mampu mengakomodasi kebutuhan-kebutuhan spesifik lembaga.

\section{Optimalisasi Pemanfaatan SIM PT}

Kerja sama pendataan antara PSP, Balitbang dengan PT di lingkungan Depdiknas pada dasarnya telah dilakukan, meski dalam bentuk yang paling sederhana, misalnya permintaan data dari PSP, Balitbang ke PT. Namun, menurut pengakuan para responden, tidak seluruh data yang diminta PSP, Balitbang tersebut tersedia di pangkalan data mereka. Oleh karena itu, ketika PSP, Balitbang meminta beberapa data dari PT, sebagian data tersebut harus mereka kumpulkan terlebih dahulu karena tidak tersedia di pangkalan data mereka. Bahkan hampir $5 \%$ responden mengakui bahwa data yang diminta PSP, Balitbang pada umumnya tidak tersedia. Penyebab paling umum adalah PT tidak melakukan pengumpulan dan pengolahan data secara baik di lingkungan lembaga mereka. Kemungkinan lainnya adalah data yang diminta oleh PSP, Balitbang bersifat khusus sehingga tidak tersedia di pangkalan data mereka.

Kenyataan ini sejalan dengan temuan studi lainnya, di mana sebanyak $61.22 \%$ responden melaporkan bahwa mereka mendapatkan data dengan meminta kepada unit-unit terkait ketika data tersebut dibutuhkan. Indikasi bahwa optimalisasi pendataan dan pemanfaatan tenologi informasi dalm pendataan di lingkungan PT masih sangat rendah.

\section{Simpulan dan Saran Simpulan}

Beberapa simpulan yang dapat ditarik melalui studi ini, adalah sebagai berikut, bahwa data mekanisme pendataan, sebagian besar PT telah melaksanakan pengumpulan dan pengolahan data secara rutin setiap tahun dan unit yang bertanggung jawab menangani dan mengelola data adalah BAAK. Bagian Perencanaan dan sistem informasi, serta bagian akademik. Pendataan yang selama ini berjalan masih didominasi oleh pengumpulan data melalui instrument kuesioner, baik oleh Ditjen Dikti maupun oleh PSP Balitbang Depdiknas. Ada dua penyebab utama terhambatnya pendataan; yang pertama berasal dari pemerintah (Ditjen Dikti dan PSP Balitbang Depdiknas), dan yang kedua berasal dari institusi PT itu sendiri. Selaku unit yang berwenang (berkewajiban) melakukan pendataan Ditjen Dikti dan PSP Balitbang tidak secara konsisten dan berkala melakukan pendataan. Masih ada responden yang merasa belum pernah mendapatkan kuesioner dari Ditjen Dikti. Separuh dari responden menerima kuesioner PSP Balitbang Depdiknas.

Hambatan yang dominan dalam pengelolaan SIM PT adalah masalah SDM, mulai dari kurangnya jumlah SDM yang tersedia, kurangnya skill yang dimiliki SDM, dan yang lain sebagainya. Permasalahan-permasalahan lainnya seperti infrastruktur, sarana dan prasarana, program aplikasi (software), dan koordinasi juga sering dihadapi oleh para responden. Di posisi selanjutnya muncul juga permasalahan keterbatasan dan anggaran, perencanaan dan pemanfaatan jaringan, pengumpulan up dating data, dan seterusnya. Belum semua PT yang menjadi sampel studi ini memiliki SIM PT. Mayoritas responden yang institusinya telah memiliki SIM PT. Dalam pengembangan dan operasionalnya, lembaga PT melibatkan berbagai unit-unit kerja lain seperti fakultas, jurusan dan program studi. Hampir seluruh responden mengakui bahwa lembaga mereka telah merancang berbagai aplikasi/program yang cocok untuk digunakan dalam SIM PT. Sebagian besar responden melakukan pengembangan aplikasi SIM PT secara mandiri. Namun, hampir separuh responden mengalihkan bahwa beberapa aplikasi yang digunakan untuk SIM PT mereka belum beroperasi dengan baik. 


\section{Saran}

Berdasarkan temuan dan simpulan yang sudah dihasilkan, disarankan agar pendataan PT yang diharapkan dapat terwujud dalm memberikan layanan data kepada pihak-pihak yang memerlukan. Sejalan dengan factor penyebab, mutlak harus mencakup perbaikan kinerja dari pihak pemerintah dan perbaikan kinerja dari pihak institusi PT itu sendiri. Unit kerja yang berwenang melakukan pendataan (Ditjen Dikti dan PSP Balitbang) perlu melakukan penjadwalan secara cermat terhadap seluruh pelaksanaan pendataan yang dilakukan. Sementara dari pihak PT, perlu lebih tanggap (responsive) terhadap permintaan data yang diterima. Pemerintah perlu membangun sistem pendataan secara on-line, atau revitalisasi sistem pendataan on-line yang sudah ada, misalnya melalui situs www.evaluasi..or.id. Situs ini hanya diperuntukkan bagi keperluan evaluasi program studi. Fungsi tersebut bisa diperlukan untuk keperluan pendataan yang lebih lengkap. Mengingat permasalahan SDM dihadapi hamper semua PT dalam pengembangan SIM PT, pemerintah perlu mencarikan jalan keluar baik dalam bentuk penyediaan fasilitas pelatihan maupun dengan mendorong institusi-institusi pendidikan untuk membuka program studi yang dapat menghasilkan lulusan yang terampil di bidangnya. Perlu dicari jalan keluar dalam masalah SDM guna pengembangan SIM PT, baik dalam bentuk fasilitas pelatihan maupun mendorong institusi-institusi pendidikan membuka program studi yang dapat menghasilkan lulusan yang terampil di bidangnya.

Mengenai permasalahan sarana prasarana dan infrastruktur serta program aplikasi pada dasarnya berkaitan erat dengan keterbatasan dana yang dimiliki PT. Oleh karena itu, upaya pemerintah dalam memfasilitasi usaha PT dalam rangka mendapatkan dana baik dalam bentuk hibah maupun pinjaman perlu ditingkatkan. Membangun SIM PT pada dasarnya adalah salah satu bentuk investasi. Dengan adanya SIM PT diharapkan dapat mendatangkan nilai (return) di masa yang akan datang sehingga pengunaan dana pinjaman layak dilakukan selama didasarkan pada analisis cost-benefit yang baik. Mengingat kebutuhan data PT yang akurat dan tepat maka keberadaan SIM PT di setiap PT mutlak dilakukan. Untuk itu, perlu diambil langkah-langkah yang lebih kongkrit untuk mendorong setiap PT agar mampu membangun SIM PT secara sungguhsungguh, salah satu caranya bisa dengan menjadikan kepemilikan SIM PT sebagai sebuah persyaratan dalam penerimaan block grant dan cara-cara lain yang sejenis dengan itu.

\section{Pustaka Acuan}

Cooper, D. R, \& Schindler, P. S. 2001. Business Research Methods, $7^{\text {th }}$ Edition. McGraw-Hill, Singapore.

Sekaran, U. (2000). Research Methods For Business: A skill Building Approach. United State of America,John Willey \& Sons,Inc.

Peraturan Pemerintah RI Nomor 61 Tahun 1999 tentang Penetapan Perguruan Tinggi Negeri sebagai Badan Hukum

Peraturan Mendiknas Nomor 38 Tahun 2008 tentang Pengelolaan Teknologi Informasi dan Komukasi di Departemen Pendidikan Nasional 